\title{
Correlation of serum leptin and insulin levels of pregnant protein-restricted rats with predictive obesity variables
}

\author{
G.S. Macêdo ${ }^{1}$, C.L.P. Ferreira ${ }^{1}$, A. Menegaz 2 , V.C. Arantes², R.V. Veloso², \\ E.M. Carneiro ${ }^{3}$, A.C. Boschero ${ }^{3}$, C.M.P. Oller do Nascimento ${ }^{4}$, M.Q. Latorraca ${ }^{1,2}$ \\ and M.H.G. Gomes-da-Silva ${ }^{1,2}$
}

${ }^{1}$ Faculdade de Ciências Médicas, Universidade Federal de Mato Grosso, Cuiabá, MT, Brasil ${ }^{2}$ Departamento de Alimentos e Nutrição, Faculdade de Nutrição, Universidade Federal de Mato Grosso, Cuiabá, MT, Brasil

${ }^{3}$ Departamento de Fisiologia e Biofísica, Instituto de Biologia, Universidade Estadual de Campinas, Campinas, SP, Brasil

${ }^{4}$ Departamento de Fisiologia da Nutrição, Universidade Federal de São Paulo, São Paulo, SP, Brasil

Correspondence to: M.H.G. Gomes-da-Silva, Departamento de Alimentos e Nutrição, Faculdade de Nutrição, UFMT, Av. Fernando Correa da Costa, s/n, 78060-900 Cuiabá, MT, Brasil

Fax: +55-65-3615-8811. E-mail: marihele@ufmt.br

\begin{abstract}
During pregnancy and protein restriction, changes in serum insulin and leptin levels, food intake and several metabolic parameters normally result in enhanced adiposity. We evaluated serum leptin and insulin levels and their correlations with some predictive obesity variables in Wistar rats (90 days), up to the 14th day of pregnancy: control non-pregnant $(\mathrm{N}=5)$ and pregnant $(\mathrm{N}=7)$ groups (control diet: $17 \%$ protein), and low-protein non-pregnant $(\mathrm{N}=5)$ and pregnant $(\mathrm{N}=6)$ groups (low-protein diet: $6 \%)$. Independent of the protein content of the diet, pregnancy increased total $\left(F_{1,19}=22.28, P<0.001\right)$ and relative $\left(F_{1,19}=5.57\right.$, $\mathrm{P}<0.03)$ food intake, the variation of weight $\left(F_{1,19}=49.79, P<0.000\right)$ and final body weight $\left(F_{1,19}=19.52, P<0.001\right)$, but glycemia $\left(F_{1,19}=9.02, P=0.01\right)$ and the relative weight of gonadal adipose tissue $\left(F_{1,19}=17.11, P<0.001\right)$ were decreased. Pregnancy $\left(F_{1,19}=18.13, P<0.001\right)$ and low-protein diet $\left(F_{1,19}=20.35, P<0.001\right)$ increased the absolute weight of brown adipose tissue. However, the relative weight of this tissue was increased only by protein restriction $\left(F_{1,19}=15.20, P<0.001\right)$ and the relative lipid in carcass was decreased in low-protein groups $\left(F_{1,19}=4.34, P=0.05\right)$. Serum insulin and leptin levels were similar among groups and did not correlate with food intake. However, there was a positive relationship between serum insulin levels and carcass fat depots in low-protein groups $(r=0.37, P<0.05)$, while in pregnancy serum leptin correlated with weight of gonadal $(r=0.39, P<0.02)$ and retroperitoneal $(r=0.41, P<0.01)$ adipose tissues. Unexpectedly, protein restriction during 14 days of pregnancy did not alter the serum profile of adiposity signals and their effects on food intake and adiposity, probably due to the short term of exposure to low-protein diet.
\end{abstract}

Key words: Low-protein diet; Pregnancy; Serum leptin; Serum insulin; Body adiposity

Research supported by the Brazilian Foundations FAPEMAT (\#175/04), CNPq (\#479138/2003-6) and FAPESP. A. Menegaz was the recipient of a FAPEMAT fellowship.

Received December 19, 2007. Accepted June 4, 2008

\section{Introduction}

The prevalence of obesity is increasing in most countries worldwide, even in those with high rates of undernutrition $(1,2)$. Obesity, cardiovascular disease, and type 2 diabetes mellitus are now prevalent among adults living in developing countries and these chronic diseases affect socioeconomically disadvantaged adults living in impoverished families. Brazilian adult population studies have shown an epidemic increase in obesity, mostly among 
women from lower social strata $(3,4)$. Although improvement in economic conditions in some families can partly explain this trend, it is possible that other factors are also important (5).

Pregnancy is a state characterized by hyperphagia $(6,7)$, decreased thermogenesis (8) and adaptations of fat cell functions, leading to an increase in adipose tissue mass during the earlier phase, followed by a decrease of fat mass during the late phase $(6,9)$. In the initial stage of pregnancy, fatty acid synthesis from glucose is increased and the lipogenic pathway predominates, whereas in the final stage the lipolytic pathway is more active (10). The net anabolic condition present in the first phase of pregnancy seems to be driven by insulin, the most efficient anabolic hormone, and its pancreatic concentration and secretion are both enhanced from early pregnancy $(11,12)$.

Low dietary protein produces hyperphagia (13) accompanied by an increase of basal metabolism (14) and adaptive diet-induced thermogenesis. This diet-induced thermogenesis is associated with increased mass and activity of brown adipose tissue (15), due to the stimulation of sympathetic nervous system (14). Despite elevation of energy expenditure, body fat content increases $(13,16)$, possibly due to positive adaptation that allows part of the excess carbohydrate ingested relative to protein to be stored as lipid (14). The increased sympathetic nervous system activity appears to contribute partly to decreased glucose-stimulated insulin secretion (17), which is compensated by enhanced glucose tolerance and insulin action seen in protein restriction (18-20).

Like insulin, leptin is involved in the modulation of energy balance by inhibiting food intake and by increasing energy expenditure mediated via activation of the sympathetic nervous system (21). Low-protein diets and pregnancy are states of leptin resistance, because food consumption is stable or increased despite a rise in plasma leptin concentration $(13,22)$. Low-protein diets during pregnancy might alter the serum insulin and leptin profile thus, contributing to the promotion of obesity among women from underdeveloped countries.

The present study evaluated the effect of low-protein diet at the end of the anabolic phase of pregnancy on serum leptin and insulin levels and the correlation of these hormones with maternal food behavior and body fat increase.

\section{Material and Methods}

\section{Animals and diets}

The experiment was carried out according to the COBEA guidelines (Brazilian College of Animal Experimentation) adopted by the Federal University of Mato Grosso, Cuiabá,
SP, Brazil (23). Twenty-three virgin female Wistar rats (90 days) were obtained from the University's Central breeding colony. Mating was performed by housing females with adult males overnight and pregnancy was confirmed by examining vaginal smears for the presence of sperm. Pregnant and virgin females were separated at random and maintained individually in polypropylene cages in a room at $24 \pm 1^{\circ} \mathrm{C}$ with lights on from 6:00 to 18:00 $\mathrm{h}$. They were fed diets and water ad libitum until the 14th day of pregnancy. During the experimental period, the animals received two types of isocaloric diets: control diet (17\% of protein) or low-protein diet (6\% of protein), described by Ferreira et al. (24). Rats were divided into four groups according to physiologic and nutritional status: control non-pregnant $(\mathrm{CNP})$, control pregnant $(\mathrm{CP})$, low-protein non-pregnant (LPNP), and low-protein pregnant (LPP). Food intake and body weight were monitored three times a week and spilling was corrected for.

\section{Sample collection and analyses}

At the end of the experimental period and after overnight fast, all rats were sacrificed, samples of blood were collected, centrifuged and aliquots of serum were used for the measurement of serum glucose by enzymatic colorimetric test (glucose oxidase method) described by Trinder (25), total serum protein by a modified reactive biuret method (26), and serum albumin using the green bromocresol method described by Doumas et al. (27). Serum insulin was determined by radioimmunoassay (28) and serum leptin was assayed by ELISA using a kit specific for rat leptin (Kits Crystal Chem. Inc., USA). The physiological index of insulin resistance used was homeostasis model assessment of insulin resistance (HOMA-IR) (29), assessed from fasting glucose and fasting insulin concentrations using the following formula: HOMA-IR = (fasting insulin [ng/mL] x fasting glucose [mg/dL]) / 22.5.

The retroperitoneal (RET) and gonadal (GON) white adipose tissues and brown adipose tissue (BAT) were removed and measured for determination of fresh weight ( $\mathrm{g}$ and $\mathrm{g} / 100 \mathrm{~g}$ of body weight, respectively). According to Gonçalves et al. procedure (30), the entire carcasses were eviscerated and dried in a forced draft oven at $80^{\circ} \mathrm{C}$ until constant weight was achieved. The content of water was determined by the difference between fresh and dry weights. Total body fat was measured by petroleum ether extraction using a continuous Soxhlet extractor and the lipid content was calculated by subtracting the fat-free dry mass from the dry carcass weight. Ash content was estimated, following combustion at $550^{\circ} \mathrm{C}$ until constant weight. Protein content was calculated by subtracting the water, fat and ash content from the wet carcass weight. 


\section{Carcass composition}

The carcass composition at the beginning of the experiment (calculated baseline energy) was estimated using the proportions of final carcass composition of the CNP group on estimated carcass initial weight (initial weight less percent of viscera weight) of the same group. From the difference between the final carcass composition and the calculated initial carcass composition, the following variables were obtained: energy gain as lipid, energy gain as protein and total energy gain. To calculate carcass energy, we assumed the energy content of protein to be $16.74 \mathrm{~kJ} / \mathrm{g}$ and fat to be $37.7 \mathrm{~kJ} / \mathrm{g}$.

\section{Statistical analyses}

The results are reported as the means \pm SEM for the number of rats indicated. Initially, the Levene test for the homogeneity of variance was used to verify the fit of the data to the assumptions for parametric ANOVA. All data were subsequently analyzed by two-way ANOVA (nutritional status and physiologic status) followed by the TukeyHSD test to determine individual differences among them, when necessary. A Box-Cox transformation was used to correct for variance heterogeneity or non-normality (31). The correlation coefficient was used to examine the association between serum leptin or insulin levels and some predictive variables of obesity. Statistical significance was taken as $P \leq 0.05$. Statistical analysis was performed using the Statistic Software package (StatSoft, Inc., USA).

\section{Results}

The total and relative food intake $\left(F_{1,19}=22.28, P<0.001\right.$ and $F_{1,19}=$ $5.57, P<0.03$, respectively), weight gain $\left(F_{1,19}=49.79, P<0.000\right)$ and final body weight $\left(F_{1,19}=19.52, P<0.001\right)$ were higher in pregnant (CP and LPP) than in non-pregnant rats (CNP and LPNP), independent of the nutritional status (Table 1).

Serum concentrations of total protein, albumin, insulin, leptin, as well as HOMA index, were not significantly different among groups. Pregnancy decreased serum glucose $\left(F_{1,19}=9.02, P\right.$ $=0.01$ ) in rats fed both diets (Table 2 ). The serum leptin and insulin concen- trations were not correlated with energy intake when group data were combined or separated according to physiological or nutritional status.

In absolute values, the fat depots of BAT were significantly increased in pregnant compared to non-pregnant rats $\left(F_{1,19}=18.13, P<0.001\right)$ as well as in low-protein compared to control rats $\left(F_{1,19}=20.35, P<0.001\right)$. BAT mass was higher only in low-protein (LPNP and LPP) compared to control groups (CNP and CP; $F_{1,19}=15.20, P$ $<0.001$; Table 3).

The absolute mass of GON and absolute and relative RET mass were similar among groups. Relative to body weight, pregnant rats exhibited lower GON values compared to non-pregnant rats $\left(\mathrm{F}_{1,19}=17.11, \mathrm{P}<0.001\right.$; Table 3).

Serum leptin concentrations were correlated positively with absolute and relative RET (Figure 1A,B) and BAT (Figure 1C,D) masses when all groups were included. When only physiological condition was evaluated, in pregnant rats there was a correlation between serum leptin concentration and RET mass $(r=0.41, P<0.01)$ as well as

Table 1. Body weight and food intake of pregnant and non-pregnant rats maintained on control or low-protein diets.

\begin{tabular}{lcccr}
\hline & CNP $(\mathrm{N}=5)$ & $\mathrm{CP}(\mathrm{N}=7)$ & LPNP $(\mathrm{N}=5)$ & LPP $(\mathrm{N}=6)$ \\
\hline Initial body weight (g) & $245 \pm 3$ & $258 \pm 10$ & $259 \pm 6$ & $250 \pm 5$ \\
Weight gain (g) & $19 \pm 8$ & $51 \pm 2^{*}$ & $17 \pm 8$ & $52 \pm 3^{*}$ \\
Final body weight (g) & $264 \pm 9$ & $309 \pm 10^{*}$ & $276 \pm 11$ & $302 \pm 4^{*}$ \\
Food intake (g) & $207 \pm 14$ & $255 \pm 11^{*}$ & $204 \pm 15$ & $263 \pm 9^{*}$ \\
Relative food intake & $78 \pm 4$ & $83 \pm 4^{*}$ & $74 \pm 5$ & $87 \pm 3^{*}$ \\
$\quad$ (g/100 g body weight) & & & & \\
\hline
\end{tabular}

Data are reported as means \pm SEM for 5-7 rats. Groups: CNP = control non-pregnant; $\mathrm{CP}=$ control pregnant; LPNP = low-protein non-pregnant; LPP = low-protein pregnant. ${ }^{*} \mathrm{P} \leq 0.05$ compared to non-pregnant groups (CNP and LPNP; two-way ANOVA).

Table 2. Serum concentration of albumin, total protein, leptin, glucose, insulin and index of insulin resistance (HOMA-IR) of non-pregnant and pregnant rats maintained on control or low-protein diets.

\begin{tabular}{lcccc}
\hline & CNP $(\mathrm{N}=5)$ & $\mathrm{CP}(\mathrm{N}=7)$ & LPNP $(\mathrm{N}=5)$ & LPP $(\mathrm{N}=6)$ \\
\hline Albumin $(\mathrm{g} / \mathrm{dL})$ & $3.45 \pm 0.16$ & $3.40 \pm 0.19$ & $3.25 \pm 0.24$ & $3.86 \pm 0.26$ \\
Total protein $(\mathrm{g} / \mathrm{dL})$ & $6.58 \pm 0.73$ & $6.53 \pm 0.25$ & $6.33 \pm 0.68$ & $6.92 \pm 0.37$ \\
Glucose $(\mathrm{g} / \mathrm{dL})$ & $77 \pm 4$ & $54 \pm 6^{*}$ & $76 \pm 5$ & $69 \pm 5^{*}$ \\
Insulin $(\mathrm{ng} / \mathrm{mL})$ & $0.51 \pm 0.15$ & $0.77 \pm 0.09$ & $0.67 \pm 0.22$ & $0.89 \pm 0.13$ \\
Leptin $(\mathrm{pg} / \mathrm{mL})$ & $2906 \pm 826$ & $4436 \pm 986$ & $3186 \pm 982$ & $4960 \pm 766$ \\
HOMA-IR & $1.79 \pm 0.58$ & $1.89 \pm 0.33$ & $2.20 \pm 0.65$ & $2.70 \pm 0.39$
\end{tabular}

Data are reported as means \pm SEM for 5-7 rats. Groups: CNP: control non-pregnant; $\mathrm{CP}=$ control pregnant; LPNP = low-protein non-pregnant; LPP = low-protein pregnant; HOMA-IR = homeostasis model assessment of insulin resistance.

${ }^{*} \mathrm{P} \leq 0.05$ compared to non-pregnant groups (CNP and LPNP; two-way ANOVA). 
serum leptin level and GON mass $(r=0.39, P<0.02)$, whereas in non-pregnant rats there was a correlation between serum leptin concentration and BAT mass $(r=$ $0.49, P<0.02$ ). Evaluation by nutritional status showed a positive correlation between leptin and RET mass and between leptin and BAT mass in protein restricted groups $(r=0.40, P<0.03 ; r=0.52, P<0.01$, respectively) and in control groups $(r=0.42, P<0.02 ; r=0.47, P<0.01$, respectively).

Carcass constituents (lipid, protein, ash, and water) in both absolute and relative values were similar among groups, except the relative carcass lipid content that was lower in low-protein groups compared to control groups $\left(F_{1,19}=4.34, P=0.05\right.$; Table 4$)$. A positive correlation between absolute content of carcass lipid and the serum concentrations of insulin $(r=0.37, P<0.05)$ and leptin $(r$ $=0.37, \mathrm{P}<0.05)$, and HOMA-IR index $(r=0.44, P<0.03)$ was observed only in low-protein groups.

Two-way ANOVA showed that carcass energy (CNP: $2086 \pm 121, N=6$; CP: $2270 \pm 207, N=8$; LPNP: $1916 \pm$ 116, $N=6$; LPP: $1998 \pm 50, N=7$ ), energy gain as lipid (CNP: $369 \pm 101$, CP: $410 \pm 176$, LPNP: $122 \pm 94$, LPP: $214 \pm 52$ ), as protein (CNP: $3 \pm 28, C P$ : $58 \pm 36$, LPNP: $28 \pm 13$, LPP: $36 \pm 29$ ), and total energy gain (CNP: $372 \pm$ 115, CP: $468 \pm 171$, LPNP: $150 \pm 91$,
Figure 1. Correlation between serum leptin $(\mathrm{pg} / \mathrm{mL})$ and absolute $(\mathrm{A})$ and relative $(\mathrm{B})$ retroperitoneal adipose tissue weight, and absolute $(C)$ and relative (D) brown adipose tissue weight of control non-pregnant rats (open circles), pregnant rats (filled circles), lowprotein non-pregnant rats (open squares) and low-protein pregnant rats (filled squares).

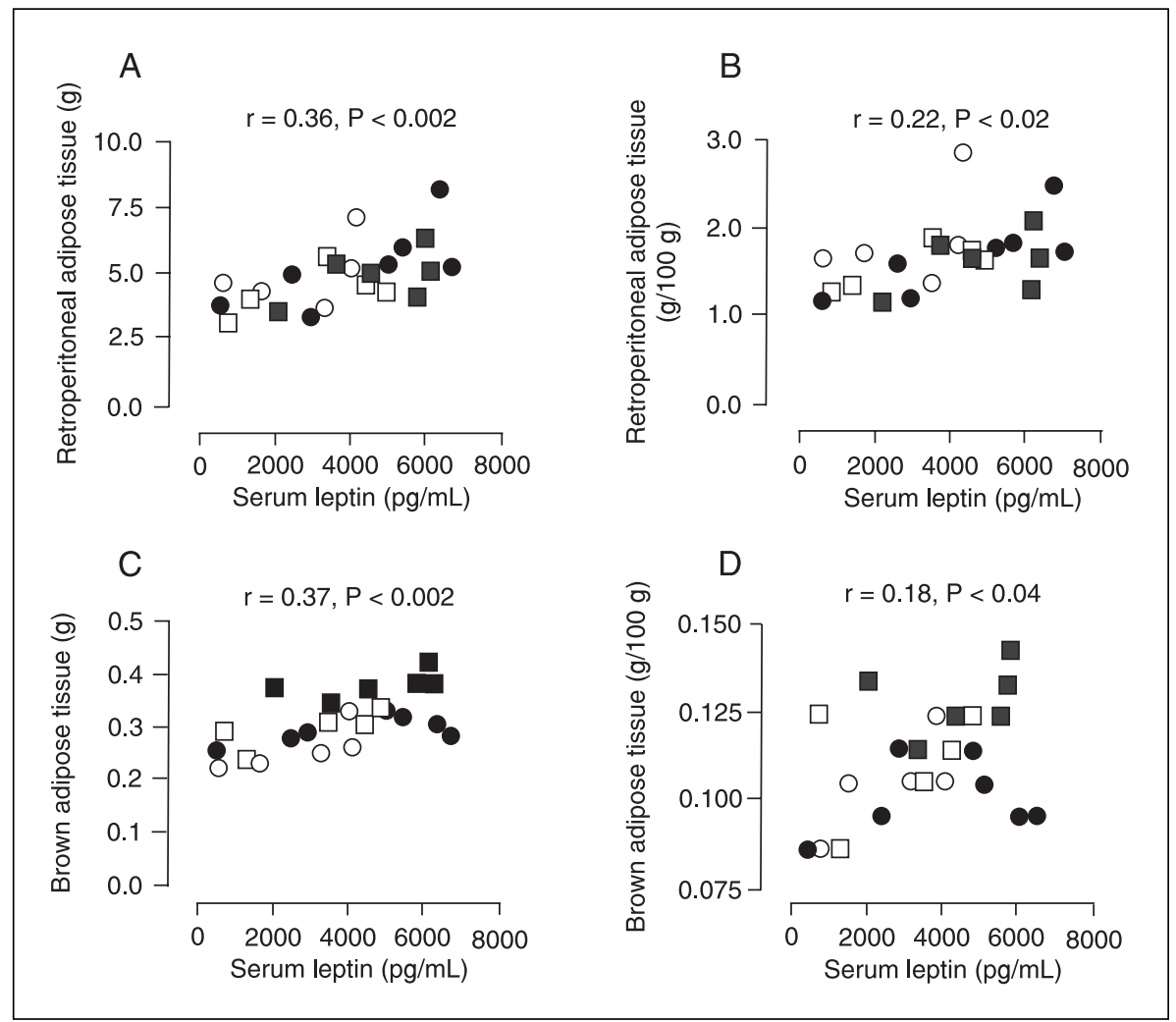


LPP: $250 \pm 48$ ) were similar among groups. Serum concentrations of leptin and insulin did not correlate with the variables when pregnant and non-pregnant groups were analyzed separated or pooled.

\section{Discussion}

Protein restriction and pregnancy are conditions commonly associated with changes in feeding pattern $(6,16)$. Studies associating these conditions have shown contradictory results. In disagreement with the results obtained by Snoeck et al. (32) that reported a small rise and by Wunderlich et al. (33) that reported reduced food intake in malnourished pregnant rats, in the present study the protein restriction during pregnancy did not produce changes in food intake. It should be noted that, contrary to this study, the low-protein diet contained $8 \%$ protein (32) and was applied during the last 2 weeks of pregnancy (33). Independent of the diet, the pregnant rats exhibited higher food intake resulting in a significant body weight gain and consequently higher final body weight, in relation to non-pregnant.

The expected reduction of serum albumin and total serum protein concentrations in response to protein restriction and pregnancy was not observed in the present study possibly due to the short term of exposure to lowprotein diet (14th day of pregnancy) and by the stage of pregnancy. The typical positive nitrogen balance seen in the normal pregnancy (34), also expected, was not observed in pregnant rats, independent of protein concentration, since the carcass protein content was similar. This can be explained by the observation that protein retaining by pregnant rats occurs especially in the later stage of pregnancy.

During the first half of pregnancy, a progressive accumulation of maternal fat depots occurs due to increased adipose tissue lipogenesis and glycerolneogenesis (35). Protein restriction is also associated with an increase in body fat content $(13,16)$. In the present study, pregnancy reduced the proportion of GON depots, while protein restriction decreased the proportion of carcass fat. In both situations, the absolute and relative weights of BAT were increased. BAT hypertrophy could be an indication of increased metabolic activity in this tissue or increased dietinduced thermogenesis. However, high diet-induced thermogenesis would explain the depletion of body lipid only in protein-restricted rats (15), but not in pregnant rats (8).
Although usually observed during the second half of pregnancy, this hypertrophy may be related to the lipid $(8,10)$ or water (7) accumulation in the tissue, and not due to increased activity of thermogenesis. This interpretation is reinforced by Frontera et al. (7) who reported an increased ratio of adrenergic $\alpha_{2}$ to $\beta_{3}$ receptors, and reduction in the number of mitochondria in pregnant rats, indicating inhibition of the sympathetic nervous system and, consequently, lower thermogenic activity in this tissue.

The reduction of GON in pregnancy can be explained by the increase of peripheric resistance to insulin, a situation that reduces the lipogenic and antilipolytic action of this hormone. Hyperinsulinemia is a common finding and occurs even before the resistance to insulin occurs in pregnancy (11). There is a correlation between insulin sensitivity and fat accumulation in maternal tissues, since women with decreased insulin sensitivity before pregnancy have difficulty increasing fat mass at the beginning of pregnancy (36). However, this explanation may be of limited value because the rats were analyzed at the end of the anabolic phase that could be the transition between increased sensitivity at the beginning, and insulin resistance in the late phase of pregnancy $(10,11)$. In addition, insulinemia and the HOMA-IR index were not affected by protein deprivation in pregnant rats. The reduction in relative carcass fat content cannot be attributed to insulin resistance because these variables did not change with protein restriction. It is possible that the reduction of abdominal fat store seen in pregnant rats reflects activation of the autonomic nervous system in response to hypoglycemia (10), a situation seen in this study only in pregnant rats.

Insulin, a food intake and energy expenditure regulator hormone, correlated only with carcass fat in protein-restricted rats. The fact that the analyses were done in the fasting insulin condition could explain the lack of correla- 
tion between insulinemia and food intake observed.

The leptin level is usually increased from the middle to the end of pregnancy (37) and in protein restriction (13). In this study, no changes were observed in leptin serum concentration in response to pregnancy or protein restriction, and this hormone did not correlate with food intake. However, similar serum leptin concentrations among groups, associated with increased food intake shown in pregnant rats, suggests a state of leptin resistance, a common situation found in the middle of pregnancy.

There is evidence that the increased plasma leptin concentrations in pregnancy do not always correlate with adiposity $(38,39)$, including BAT depots $(7)$, while protein restriction correlates directly with carcass fat content (13). In the present study, there was a positive relationship between serum leptin level and absolute and relative weights of RET and BAT, when all groups were considered for analysis. However, in pregnant rats this hormone correlated with abdominal fat depots of RET and GON, while in non-pregnant rats there was correlation only with BAT mass. A direct correlation between leptin and fat carcass, RET and BAT in protein-restricted rats was observed. Thus, serum leptin concentration in pregnancy seems to reflect the abdominal fat content, while the protein restriction reflects total fat content.

These results allow us to conclude that protein restriction in this period of pregnancy (14 days) did not increase adiposity or alter the serum insulin and leptin levels. Moreover, these hormones did not correlate with the predictive obesity variables, possibly due to the short term of exposition to low-protein diet.

\section{Acknowledgments}

The authors thank C.R. Afonso, from Departamento de Alimentos e Nutrição, Faculdade de Nutrição/UFMT, for technical assistance.

\section{References}

1. WHO (World Health Organization). Obesity: preventing and managing the global epidemic. Geneva: World Health Organization; 1997.

2. Popkin BM, Doak CM. The obesity epidemic is a worldwide phenomenon. Nutr Rev 1998; 56: 106-114.

3. INAN (Instituto Nacional de Alimentação e Nutrição). Condições nutricionais da população brasileira: adultos e idosos. Pesquisa Nacional de Saúde e Nutrição. Brasília: INAN/Ministério da Saúde; 1991.

4. Florêncio TT. Obesity in adult population residing in a "sem teto" - homeless encampment in the northeast of Brazil. Intern J Obes 1998; 22: 245S.

5. Popkin BM, Bisgrove ES. Urbanization and nutrition in lowincome countries. Food Nutr Bull 1988; 10: 3-23.

6. Herrera E, Lasuncion MA, Palacin M, Zorzano A, Bonet B. Intermediary metabolism in pregnancy. First theme of the Freinkel era. Diabetes 1991; 40 (Suppl 2): 83-88.

7. Frontera M, Pujol E, Rodriguez-Cuenca $S$, Catala-Niell $A$, Roca P, Garcia-Palmer FJ, et al. Rat brown adipose tissue thermogenic features are altered during mid-pregnancy. Cell Physiol Biochem 2005; 15: 203-210.

8. Abelenda M, Puerta ML. Inhibition of diet-induced thermogenesis during pregnancy in the rat. Pflugers Arch 1987; 409: 314-317.

9. Lopez-Luna P, Maier I, Herrera E. Carcass and tissue fat content in the pregnant rat. Biol Neonate 1991; 60: 29-38.

10. Ramos MP, Crespo-Solans MD, del Campo S, Cacho J, Herrera E. Fat accumulation in the rat during early pregnancy is modulated by enhanced insulin responsiveness. Am J Physiol Endocrinol Metab 2003; 285: E318-E328.

11. Munoz C, Lopez-Luna P, Herrera E. Glucose and insulin tolerance tests in the rat on different days of gestation. Biol
Neonate 1995; 68: 282-291.

12. Sorenson RL, Brelje TC. Adaptation of islets of Langerhans to pregnancy: beta-cell growth, enhanced insulin secretion and the role of lactogenic hormones. Horm Metab Res 1997; 29: 301-307.

13. Du F, Higginbotham DA, White BD. Food intake, energy balance and serum leptin concentrations in rats fed lowprotein diets. J Nutr 2000; 130: 514-521.

14. Even PC, Bertin E, Gangnerau MN, Roseau S, Tome D, Portha B. Energy restriction with protein restriction increases basal metabolism and meal-induced thermogenesis in rats. Am J Physiol Regul Integr Comp Physiol 2003; 284: R751R759.

15. Rothwell NJ, Stock MJ. Influence of carbohydrate and fat intake on diet-induced thermogenesis and brown fat activity in rats fed low protein diets. J Nutr 1987; 117: 1721-1726.

16. White BD, Dean RG, Martin RJ. An association between low levels of dietary protein, elevated NPY gene expression in the basomedial hypothalamus and increased food intake. Nutr Sci 1998; 1: 173

17. Leon-Quinto $T$, Adnot $P$, Portha $B$. Alteration of the counterregulatory hormones in the conscious rat after protein-energy restriction. Diabetologia 1997; 40: 1028-1034.

18. Okitolonda W, Brichard SM, Henquin JC. Repercussions of chronic protein-calorie malnutrition on glucose homeostasis in the rat. Diabetologia 1987; 30: 946-951.

19. Escriva F, Kergoat M, Bailbe D, Pascual-Leone AM, Portha $B$. Increased insulin action in the rat after protein malnutrition early in life. Diabetologia 1991; 34: 559-564.

20. Picarel-Blanchot F, Alvarez C, Bailbe D, Pascual-Leone AM, Portha B. Changes in insulin action and insulin secretion in the rat after dietary restriction early in life: influence of 
food restriction versus low-protein food restriction. Metabolism 1995; 44: 1519-1526.

21. Havel PJ. Peripheral signals conveying metabolic information to the brain: short-term and long-term regulation of food intake and energy homeostasis. Exp Biol Med 2001; 226: 963-977.

22. Seeber RM, Smith JT, Waddell BJ. Plasma leptin-binding activity and hypothalamic leptin receptor expression during pregnancy and lactation in the rat. Biol Reprod 2002; 66: $1762-1767$.

23. Comissão de Ensino do Colégio Brasileiro de Experimentação Animal (COBEA). Manual para Técnicos em Laboratórios. 2nd edn. 1996.

24. Ferreira CL, Macedo GM, Latorraca MQ, Arantes VC, Veloso RV, Carneiro EM, et al. Serum leptin and insulin levels in lactating protein-restricted rats: implications for energy balance. Br J Nutr 2007; 97: 27-34.

25. Trinder $P$. Determination of blood glucose using an oxidaseperoxidase system with a non-carcinogenic chromogen. $J$ Clin Pathol 1969; 22: 158-161.

26. Wolfson WQ, Cohn C, Calvary F, Ichiba F. Studies in serum proteins. A rapid procedure for the estimation of total protein true albumin, total globulin, alpha globulin and gamma globulin in $1.0 \mathrm{~mL}$ of serum. Am J Clin Pathol 1948; 18: 723-730.

27. Doumas BT, Watson WA, Biggs HG. Albumin standards and the measurement of serum albumin with bromcresol green. Clin Chim Acta 1971; 31: 87-96.

28. Scott AM, Atwater I, Rojas E. A method for the simultaneous measurement of insulin release and $B$ cell membrane potential in single mouse islets of Langerhans. Diabetologia 1981; 21: 470-475.

29. Pacini G, Mari A. Methods for clinical assessment of insulin sensitivity and beta-cell function. Best Pract Res Clin Endocrinol Metab 2003; 17: 305-322.
30. Gonçalves EL, Waitzberg DL, Bevilacqua RG, Bevilacqua LR. Body composition in various nutritional conditions. Experimental study. Rev Paul Med 1990; 108: 125-133.

31. Sokal RR, Rohlf FJ. Assumptions of analysis of variance. In: Sokal RR, Rohlf FJ (Editors), Biometry: the principles and practice of statistics in biological research. New York: W.H. Freeman and Company; 1995. p 392-450.

32. Snoeck A, Remacle C, Reusens B, Hoet JJ. Effect of a low protein diet during pregnancy on the fetal rat endocrine pancreas. Biol Neonate 1990; 57: 107-118.

33. Wunderlich SM, Baliga BS, Munro HN. Rat placental protein synthesis and peptide hormone secretion in relation to malnutrition from protein deficiency or alcohol administration. $J$ Nutr 1979; 109: 1534-1541.

34. Beaton GH, Beare J, Ryu MH, McHenry EW. Protein metabolism in the pregnant rat. $J$ Nutr 1954; 54: 291-304.

35. Palacin M, Lasuncion MA, Asuncion M, Herrera E. Circulating metabolite utilization by periuterine adipose tissue in situ in the pregnant rat. Metabolism 1991; 40: 534-539.

36. Catalano PM, Roman-Drago NM, Amini SB, Sims EA. Longitudinal changes in body composition and energy balance in lean women with normal and abnormal glucose tolerance during pregnancy. Am J Obstet Gynecol 1998; 179: 156165.

37. Ehrhardt RA, Slepetis RM, Bell AW, Boisclair YR. Maternal leptin is elevated during pregnancy in sheep. Domest Anim Endocrinol 2001; 21: 85-96.

38. Ehrhardt RA, Bell AW, Boisclair YR. Spatial and developmental regulation of leptin in fetal sheep. Am J Physiol Regul Integr Comp Physiol 2002; 282: R1628-R1635.

39. Gavrilova O, Barr V, Marcus-Samuels B, Reitman M. Hyperleptinemia of pregnancy associated with the appearance of a circulating form of the leptin receptor. $J$ Biol Chem 1997; 272: 30546-30551. 